\title{
The Role of Subsidiarity and Proportionality Principles in the Development of a Future Digital Single Market and a Common European Contract Law
}

\author{
Ovidiu Ioan DUMITRU \\ Bucharest University of Economic Studies, Bucharest, Romania \\ ovidiu.dumitru@drept.ase.ro
}

\begin{abstract}
From the far beginning of the European Communities, with broader objective of creating a perfect unique market for the member states, it must be underlined the importance of the results of the harmonisation process of the contract law and the single market and that, in time, the institutions struggled in their tumultuous work for fulfilling the indicated objectives to overcome the interventions from each Member State, interested, also, in shaping a great and prosperous common market, but trying, subsequently, to reason with their traditions, culture, ideological and political choices. The legislation on single market and European contract law is a subjected to the three guiding principles of the European Union: the principle of conferral, which empowers the European Union in terms of competence, the principle of subsidiarity, which underlines the European Union's competence in a certain field that is shared with a Member State and the principle of proportionality, which applies if the first two principles are validated, dealing with the how the European Union should legislate. However, there are some critics who express their worries in that there are insufficient empirical proofs for redefining the harmonisation process. Taking into account the criticism, the European Court of Justice has ruled in numerous occasions that the authorisation to harmonise laws, with the scope of safeguarding the proper functioning of the European internal market does not grant the European Union a carte blanche in order to interfere with the sake of harmonisation any law it wishes. The way the above indicated principles maintained their roles provided by the treaties or they were subject of modification, by enrichment or limitation, by the caselaw provided by the European Court of Justice, we must investigate in order to picture a possible "finale" of our Single Market and this paper will concentrate of the influence of subsidiarity and proportionality on the fields most dynamic in the past years, the Digital Single Market and its contract law. This paper wishes to clarify how the two fundamental principles, of subsidiarity and proportionality, provided in time by the modifying treaties and consolidated by the European Court of Justice, influenced the evolution of the legislation regarding the Single Market and how those two may help or block the future evolution in the context of a continuous pressure coming from the development of the digital framework and online contracts.
\end{abstract}

Keywords: subsidiarity, proportionality, digital market, European contract law, Single European Market.

\section{Introduction}

The European Union legal order is characterised by autonomy, in the idea that it constitutes a legal system which is different from the international legal order, although, formally, it belongs to it, and the national legal systems of Member States, being a supranational one, considered a common internal law of all the members. (Lefter, 2003, p. 49). The opinion that European Union Law, as a legal structure based on treaties concluded by states, should be linked to the international law was for a period very consolidated among the authors (Wyatt, 1982, p. 147), but as the European Court of Justice stated in its pivotal cases Van Gend en Loos and Costa, European Union Law is a "a new legal order", so many authors decided to lean towards the constitutionalism theory rather than internationalism (Spiermann, 1999; De Witte, 2014), considering that European Union has passed to new level, unique among the international organisations (Moravcsik, 2007).

The qualification of the European Union Law as a new legal order characterised by specific features, leaded to a debate on the collaboration between the national legal systems and 
the new created one, as the specific caselaw explained that EU law is not just a new type of international, unique in its features, but it, also, becomes national law, based on the exclusive competence power conferred by the treaty provisions. Consequently, there was an increased need to analyse and decide on the relation between the Members States and European Union mainly in legislating for the development of the supranational structure provided in the treaties.

The principles to be enacted for the clarification of the relation between the Member States and European Union were the ones of subsidiarity and proportionality, which are playing an important role in the decision making process of the European Union, with the main purpose of balancing the powers between the European Union and the Member States and taking the appropriate measures for the fulfilment of the objectives provided. (Lefter, 2003, p. 78).

The focus of the paper is on the analysis of the subsidiarity and proportionality and their influence on the evolution of the internal market, especially taking into consideration the latest developments related to digital matters.

\section{Subsidiarity, Proportionality and the Single Market Subsidiarity}

Subsidiarity is established, together with conferral and proportionality, in Article 5 of the Treaty on European Union and the protocol "On the application of the principles of subsidiarity and proportionality". It was first formally provided in the Maastricht Treaty, following a mention in the Single European Act related to environment (Henkel, 2002) and the resulting ruling by the Court of First Instance of the European Communities declaring that it wasn't a general principle of law (case T-29/92/1995).

Subsidiarity enacts the conditionality for the European Union to act only it is in a better position than the Member States in achieving some objectives and that added value can be brought if the action is carried out at Union level. Still, its appearance came more as a defence by the Member States against the continuous expansion of the Communities following the SEA (Estella, 2002).

The evolution of amendments on the founding treaties and the secondary European legislation, sustained by interpretation offered by the European Court of Justice started raising questions on the centralisation of the legislative process, so the Member States decided to introduce a way to limit the tendency (Davies, 2006) as well as they tried to clarify the competence of the two legislators, European and national one (Soares, 1998).

Furthermore, the Lisbon Treaty, developed the area of subsidiarity and introduced new mechanisms ensuring the control of subsidiarity ex ante and also ex post the legislative process, by this, strengthening the role of national parliaments and the role of the Committee of Regions. Moreover, this was also a useful tool for establishing the legitimacy of the decision-making process at EU level.

Regarding the features and application of subsidiarity, there are, still, some divergent opinions, the principle being appreciated by some authors (Craig \& Burca, 2011) for its flexibility as a response to the dynamic balance of competences between the levels of power within the Union and of the Member States, but for others, the same flexibility is viewed in fact as ambiguity, which makes the principle inoperative (Estella, 2002)

Nonetheless, subsidiarity has indeed become a consistent presence in legal debates, being regarded both from the perspective of the objectives of development, strengthening the integration process, and from the preservation of national states' sovereignty. Moreover, this duality is coming as an effect of the constant change of objectives, mainly related to the single market.

The subsidiarity is an evidence of the European view on assigning the power to take decisions as close to the citizens as possible (Craig \& Burca, 2011), ranging from the local authorities to governmental ones and finally to the European institutions for those matters with 
a cross-border or international dimension, without a specific distribution given by the treaties or caselaw (case C 359/92, 1994). There are many factors that were taken into account when decided that the best approach for fulfilling an objective is to issue measures suited for the citizens:

- the lower the level of the decision-making process, the higher the awareness of individual preferences;

- a more decentralised decisional system leads to efficiency and innovation;

- the smaller the number of people involved in the decisional process, the greater their influence in the outcomes (Bernholz, 2009).

The question to be answered is how to assign the right to adopt measures in a certain matter, in order to fully fulfil the objectives, and how are we testing the effectiveness of that choice?

To determine whether a matter is to be addressed at Union or national level, some authors (Syrpis, 2004) identify two possible tests: a negative one checking if the Member State cannot fulfil, in a sufficient way, the objective proposed, and a second one, positive, which is checking if there is any added value if the Union acts. However, the process of answering the two questions should be carefully assessed as it cannot presume that in the case of inability to fulfil an objective at the national level, the European legislation is automatically needed. It is necessary to analyse if, by its involvement, the EU can bring any added value. (Bercea, 2007). Some opinions even suggest that subsidiarity is unfair for the stated purpose as it "privileges (the) achievement (of the Union objectives) absolutely" and by that disregarding the Member States' autonomy. (Davies, 2006)

\section{Proportionality}

The principle of proportionality is also mentioned, together with the subsidiarity, in Article 5 of the TEU and in Protocol No. 2 of that Treaty. However, it has been recognised as legal constrain on legislative and administrative action long before the other. It is considered that it was acknowledged by the founding treaties and the caselaw (Case C8/45, 1954; Case C 11/70, 1970) as a proof of its existence in all the legal systems of the Member States. (Bercea, 2007).

After the slight mentioning in the founding treaties and following jurisprudence, the concept of proportionality has been further developed by the European Court of Justice (Case C-331/88, 1990), clarifying that when there is a choice between several appropriate measures, the least one must be adopted, and any disadvantage caused must not be disproportionate to the aims pursued.

The principle of proportionality, as provided in the treaties, refers to the limitation of EU action to what is necessary for the achievement of the objectives, meaning that the content and form of the action must be in line with the aim pursued, as laid down in Article 5 of the Treaty on European Union.

The European caselaw reviewed this principle and empowered it as a general principle of law, applicable both to the European institutions, as well as to the Members States enforcing the European provisions. (case C-122/78, 1978; Case C-39/75, 1975; Case C-36/75, 1975)

Legal doctrine (Craig \& Burga, 2011) and, mainly, the Court by its judgments, have enacted a form of a test needed to declare a measure being proportional:

1) if it is suitable to achieve a legitimate aim. The suitability test is based on the evaluation of the effects the measure may attain within the field of application (Henkel, 2002). The moment of enactment is important, as suitability cannot be questioned in the retroactive sense (Case C 276/80, 1982).

2) if less restrictive alternatives could be employed (Case C8/55, 1955), however, among equally suitable options, the European legislator has a certain level of discretion and its own scope of judgement (Case C-280/93) 
3 ) if the measure should not have an excessive effect on the applicant's interests, thus weighing the advantages and disadvantage of the proposed measure and maintaining a balance between intended goals and the damages the new measure produces. (Case C5/73, 1973)

In acting for the fulfilment of the objectives, each European institution has the duty to "ensure constant respect" of the proportionality principle by offering a "detailed statement accompanying draft legislative acts", as it is stipulated in art 5 of the Protocol No. 2 annex to the treaty on European Union. However, in comparison to subsidiarity, proportionality cannot be communicated through an early warning mechanism or special provisions of judicial review. (Bradley, 2014)

\section{The European Single Market}

One of the main objectives of the Member States, from the very beginning, was the creation of a functional common market and the Court of Justice of European Union, in one of its judgements (Case 270/80, 1982), trying to explain the special nature of the European legal system, explained, in relation to the common market, that "the Treaty (...) seeks to create a single market reproducing as closely as possible the conditions of a domestic market", so the relations between the internal markets are seen as being of an internal legal order, common to all Member States and not belonging to international law. (Manolache, 2003)

As the Court presented, among the first aspirations of the Member States of European Union has always been the creation of a unique Single Market, without any internal barriers, enjoying the free movement of goods, persons, services and capital in a common tariff zone and functional competition between the merchants from different countries.

The development of the European Internal Market has a long history, from the first steps passing now more than 50 years and, still, we cannot conclude that certain areas are clearly defined, the role of the Court of Justice being crucial in interpreting and providing new principles, most of the enrichment process being based on the substitutes offered by the caselaw.

As to the main role attributed to the institutions and states for the fulfilment of the Single Market, there can be identified the action in the integration of the national ones into a single European market and that has to be fulfilled by removing all possible obstacles to trade between states, the rationale, explained by the Court (Case 15/81, 1982), for pursuing such a project being not purely economic, but also social and political, as for many, the market defines a form of ordoliberalism, but also supplies a greater degree of uniformity of structure and conditions. (Charmers et. all, 2010).

The nature of European market integration changed in time, just as the paradigm from Rome Treaty to develop a common market was replaced later by the single market paradigm, when the substantive law moved towards a more competitive model with the home country holding a greater role. Today, we can witness the third one called Economic Union, where the market and the monetary union "complement each other" (Snell, 2014) with benefits of using a single currency in a well-functioning internal market, but with questions raised on the reduced flexibility, seen in the last financial crisis (Moloney, 2010 ).

One of the reasons for this new approach is the increase of digitalisation which leads also to a faster and smoother cross-border process in the internal market, many goods, services persons and, definitively, capital transferring a lot easier from one member state to the another and by that resetting the initial view on freedoms.

\section{Subsidiarity, Proportionality and the Internal Market}

The main conflict regarding the internal market focuses on the balance between the centralised level, where the majority of the economic decisions are being taken exclusively by the Union, 
leaving behind the competences of the Member States - a laissez-faire approach, and decentralised level, where the regulation of the economic system is, this time, left in the hands of national regulators - laissez-regler approach (Weatherill, 2010). A significant aspect lies also in the fact that by approaching a decentralised path, the emphasise is placed on the democratic principles, while the centralised approach places value on effective economy. Subsidiarity and proportionality can be seen as a solution for ensuring the legitimacy of the EU legislative process in regulating the internal market, while providing the choice between the centralist and decentralist approaches, in this way contributing to establishing the balance between the national traditions of the member States and the common goals of the internal market of the Union.

There are no clear answers to the optimal level of centralisation and the opinions of the scholars continue to be divergent (Henke, 2006), so the European institutions, in their job to fulfill the creation of a functional and adapted market, have to adjust a range of factors from case to case in order to benefit from institutional complementary European system and use the added value of the EU legislation. Applying subsidiarity and proportionality in accordance with the provisions from the treaties, caselaw and even doctrine, may bring a balance between economic efficiency and balanced growth and by that the EU's added value can be extracted without creating regional inequality.

Nevertheless, the centralised action means that Member States must surrender their regulatory powers in order for the issue to be better handled at the collective level. In relation to matter under debate, we have to accept that the cases of potential market distortions, where some Member States went in a way and others in a different one, by that attracting the necessity to ensure that competition is not distorted, can justify Union action (Öberg, 2016).

As regarding the evolution of economic growth following the reshaping of the market integration theories, especially the transfer in the treaties from common to internal market with a higher harmonisation perspective, we can notice that EU policies are not the ones driving the growth, as it is managed mainly by the national policies, still, they can boost it and create some type of convergence.

The decision to centralise or de-centralise has to be taken in accordance with the possible benefits to be secured compared to the costs spend for those and, in that regard, we have to analyse the factors that may lead us one way or the other. Therefore, when we are in a situation of economies of scale with positive externalities, the centralisation may be the choice, but when the local environment is very different, the economic theory suggests that there is little added value in case of a centralised decision and we shout orientate towards the national better suited decisional process.

The objective of this article was to analyse how is better to approach the achievement of certain objectives of market integration, in a more centralised way or locally, subsidiarity and proportionality being the principles applicable in deciding this. For attaining the possible results which may help us see on which is the way to go, I decided to overview a current issue which, especially our current pandemic crisis, is raising questions on the integration of the Single Market, the digitalisation of the market with a special focus on latest updates from European Contract Law.

\section{Subsidiarity, Proportionality and the Internal Market in the Digital Era}

The future reserves us new ways to handle the market integration and the present pandemic crisis has shown us that digitalisation may be an pivotal instrument in assessing the measures for shaping a new form of Single Market, with individuals, companies or states more connected.

The European Union has decided to act and it came with some rules following the 30 legislative proposals of Juncker Commission part of the 2014-2019 strategy on Digital Single Market. There were enacted common rules for online sales, revised Payment Services Directive, 
revised consumer protection rules, new rules on cross-border parcel delivery services that are already in force, removal of geo-blocking for streaming services, new VAT rules for online sales of goods and services, a new Regulation on the free flow of non-personal data but the strategy still needs to be followed by new proposals which may, in the end, lead to a unified digital Single Market.

We have to understand that most of the proposals are in the form of Directives, needing implementation, but even in case of Regulations, a bigger issue is that these rules expanding across the EU mean that the digital businesses need to deal with 28 jurisdictions having their own way of dealing with the fields touched now by the digital world.

Consequently, the current state of digital Single Market, being under construction and raising questions in relation to the possibility to be applied in the same manner in all Member States, makes all of us starting questioning of the use of subsidiarity and proportionality, analysing the existence of an added value in solving these issues at EU level. By applying the principles of subsidiarity and proportionality, EU will choose a path orientated towards a common good perspective: in areas where the EU can provide a value added for citizens, it should indeed act and, this way, provide a common good. This can take various forms, like specific regulation in the Single Market or leadership in crisis situations. But any such EU-level action should be guided by the idea that member states and its citizens are provided with a clearcut value added. Conversely, in areas where it may not be capable of providing such value added, national or subnational governing bodies should take the lead.

Among all the proposals and enacted rules shaping the new Digital Single Market, I decided to concentrate on the the ones related to Contract Law and analyse how fulfilling the subsidiarity and proportionality tests can help the increase of harmonisation of this very nationalised area in the context of the development of the Digital Single Market.

The Europeanisation of contract law by enacting rules at EU level is a crucial instrument for the improvement of the functioning of the internal market, but this process raises questions as regarding the competence, whether the Member States should continue legislating on their own or there might be a positive aspect in the involvement of European union, forcing maximum harmonisation of the field, an aspect which brings us to question how successful are the principles of subsidiarity and proportionality in the field of contract law in the perspective of the new Digital Single Market.

The European Commission, as an effect of the continuous pressure for the harmonisation of contract law and following the work of scholars, presented in 2011 the proposal for Common European Sales Law (CESL), intended to take the form of a Regulation and be applied to cross border transaction, but it was met with resistance ( Eidenmueller and others, 2012, pp. 356-357), mainly due its pursued standardisation, so the Juncker Commission decided to reorientate towards certain pivotal issues needed to be assessed in the field of online commerce and issued two directives, one on certain aspects of contracts for the supply of digital content and the other for online contracts and other distance sale of goods, aiming to fully harmonise the key binding rights and obligations of the parties of a contract for the supply of digital content and the online sales of goods. (Merdi T.P., 2017)

The European Commission decided to switch from unification to total harmonisation, and although, in theory, this change cannot be assumed to be wrong considering the limited substantive content of the acts, in reality the idea of adopting two full harmonisation directives may be problematic, as it opens up the possibility of fragmentation of EU law, as well as of the reduction of consumer protection at national level and by that start questioning the subsidiarity and proportionality of the proposals.

Many authors (Manko, 2016 \& Beale, 2016) criticised the choice of full harmonisation as some of the provisions, proposals at that time, are "leaving the Members States with no room for manoeuvre" by intrusion in the specific consumer protection legislation and force them to 
take measures towards a standardisation, without a clear benefits "neither in favour of consumers, nor in favour of businesses". These critics raise problems of subsidiarity, questioning the process of testing the "added value" brought by Union legislative process, or proportionality as the full harmonisation measures will lead to significant reductions in consumer protection in various Member States. The critics considered that the two proposals, in some aspects are more intrusive and the previous failed proposal for Common European Sales Law (Beale, 2016)

From the application point of view, we notice that the two Directives have changed fundamentally their territorial scope from the previous failed proposal and provide that the provisions are to be applied to both cross border contracts, as in CESL, and domestic ones, the Commission explaining that there was a need of fully harmonised rules for digital content and for the online sales of goods, both domestically and cross-border, for ensuring an harmonised high level of consumer protection throughout the EU which will facilitate businesses to sell goods in the EU.

The Commission's explanation on extending the effects to domestic contracts may be criticised mainly from a constitutionalism perspective, as many might say that subsidiary and proportionality are requiring a limitation on the application only to cross-border transactions, as the "individual Member States cannot create a legal framework to regulate cross-border transactions that would be applicable in all the other Member State" (Flesner, 2001), allowing the EU to adopt measures in that way, but interfering with the national jurisdiction in regulating the specific contract law provisions might be considered not in accordance with the principles provided by art. 5 TFEU as "subjecting internal and cross-border contracts to different legal regimes is in fundamental opposition to the spirit of the internal market" (Lando, 2011)

Yet, this approach can be considered a conservative one and there can be found arguments to explain why this extension to domestic contracts may, still, be, overall, a positive adjustment. One of the clear advantages of full application is that to the customers will be addressed only one operating system and not parallel ones, no matter if the seat of the business is in the same or another Member State (Fuchs, 2011) and if we go back to the subsidiarity and proportionality tests, we have to acknowledge that "the general goal of attaining a functional internal market cannot be attained regardless of divergences among the legal systems of the different Member States" (Arroyo Amayuelas, 2016) by risking market fragmentation due to inability to establish clear criteria for "distinguishing between domestic and cross-border contracts" (Bosedow et. others, 2011) and the process of reducing the disparities cannot be achieved by the Member States themselves. (Twigg-Flesner, 2013)

\section{Conclusions}

The present article had as main scope the analysis of how much the harmonisation process of the Digital Single Market, especially of the new acts in European Contract Law, is following the subsidiarity and proportionality principles enacted by the treaties, by that continuing the relation EU - Member States started by Maastricht or it is changing the paradigm, taking into consideration the new digital revolution.

One of the conclusions is that the subsidiarity principle sets a higher level for justifying harmonisation of national laws, especially because of the obstacle created in acting for creating cross-border transactions, so it seems hard to proceed with a extensive harmonisation of all areas of the Single Market, but there are certain fields like consumer contract law which are are passing the tests.

Moreover, after checking if harmonisation is compatible with subsidiarity, there is a further hurdle to overcome: EU action has, also, to comply with the proportionality principle and some may say that harmonisation, which is both intrusive and disruptive to national legal 
systems, complies with the proportionality principle only if the standard pursued would be full harmonisation rather than minimum one.

Nevertheless, I may conclude that the centralisation may be considered in line with the subsidiarity and proportionality principles as long as by harmonising national law there would be a single set of rules to encourage consumers and traders to make the most of the internal market.

\section{References}

Arroyo Amayuelas E (2016) The idea of an optional contract code. In: Twigg Flesner C (ed) Research handbook on EU consumer and contract law. Edward Elgar, Cheltenham/Northampton, pp 463-486

Basedow J and others (2011) Policy Options for Progress Towards a European Contract Law: Comments on the issues raised in the Green Paper from the Commission of 1 July 2010, COM (2010) 348 final. Max Planck Private Law Research Paper No. 11/2

Beale H (2016) Scope of application and general approach of the new rules for contracts in the digital environment, In-Depth Analysis. European Parliament - Policy Department for Citizen's Rights and Constitutional Affairs

Bercea R. (2007) Drept comunitar. Principii, C.H. Beck Publishing House,

Bernholz P. (2009) How to safeguard Subsidiarity and Competition in the European Union, RMM Journal, Vol. 0

Bradley St. C. K. (2014). Legislating in the European Union, in Barnard C. \& Peers S (eds.), European Union Law, Oxford University Press, p. 116

Chalmers D. , Davies G. (2010) Monti G., European Union Law, 2nd edition, Cambridge University Press

Craig P. \& de Burca G. (2011) The Evolution of EU Law, Oxford University Press

Davies G. (2006) Subsidiarity: the Wrong Idea, in the Wrong Place, at the Wrong Time, Common Market Law Review, no. 1

Eidenmueller $\mathrm{H}$ and others (2012) The proposal for a regulation on a common European sales law:shortcomings of the most recent textual layer of European contract law. Juristenzeitung, pp 269-289

Estella A. (2002) The E.U. Principles of Subsidiarity and its Critique, Oxford University Press Fuchs A (2011) European contract law: the way forward. ERA Forum 12(1):1-5

Henke, K.D. (2006). Soft Coordination and Hard Rules in European Economic Policy managing Subsidiarity from an Economic Point of View, Intereconomics

Henkel C. (2002) The Allocation of Powers in the European Union: A Closer Look at the Principle of Subsidiarity, Berkeley Journal of International Law, Vol. 20:359

Lando O (2011) On a European contract law for consumers and businesses - future perspectives in Schulze R, Stuyck J (eds) Towards a European contract law. Sellier European Law Publishers, Munich, pp 203-216

Lefter C. (2003). Fundamente ale dreptului comunitar instituţional, Economica Publishing House

Manko R (2015) Contract law and the Digital Single Market: Towards a new EU online consumer sales law? In-Depth Analysis, European Parliamentary Research Service

Manolache O. (2003) Drept comunitar, Ediția a IV a, All Beck Publishing House, Bucharest,

Merdi T.P. (2017), The Proposed New Digital Single Market Contact Law Directives: A New Start for Digital European Contract Law?, in Synodinou T.-E. et al. (eds.), EU Internet Law

Moloney N. (2003) EU Financial Market Regulation after the Global Financial Crisis: More Europe or More Risk?, Common Market Law Review, vol. 47, issue 5, p. 1317-1383 
Moravcsik, A. (2007) The European Constitutional Settlement, in Meunier S. And McNamara K. (eds.) Making History: European Integration and Institutional Change at Fifty, Oxford University Press

Öberg J. (2016), Subsidiarity as a Limit to the Exercise of EU Competences, Yearbook of European Law, pp. 1-30

Snell J. (2014) The Internal Market and the philosophies of market integration, in Barnard C. PICBE | 1186 \& Peers S., European Union Law, Oxford University Press

Soares G. 1998. Preemtion, Conflicts of Power and Subsidiarity, European Law Review, no. 2, p. $132-145$

Spiermann, O. (1999) The Other Side of the Story: An Unpopular Essay on the Making of the European Community Legal Order, European Journal of International Law, Vol. 10, No. 4

Syrpis P. (2004). In Defence of Subsidiarity, Oxford Journal of Legal Studies, Volume 24, Issue 2

Twigg-Flesner, Christian. (2013) The Europeanisation of Contract Law: Current Controversies in Law, second edition, Routledge

Twig-Flesner C (2011) Good bye harmonisation by directives, Hello Cross - border only, regulation? - A way forward for EU consumer contract law. European Review Contract Law 7 (2), p.235-256

Weatherill (2010) Cases and Materials on EU Law, Ninth Edition

De Witte B. (2014) E.U. Law: Is It International Law? in Barnard C. \& Peers S (eds.), European Union Law, Oxford University Press, p. 174-180

Wyatt, D. (1982). A new Legal Order or Old?, European Law Review,

\section{Caselaw}

Vereniging van Samenwerkende Prijsregelende Organisaties in de Bouwnijverheid and others v Commission of the European Communities (1995) T-29/92

Germany v. Council (1994) C 359/92

Federation Charbonniere de Belgique v High Authority (1954) Case C8/55

Internationale Handelsgesellschaft v Einfuhr- und Vorratsstelle Getreide (1970) Case 11/70

R v Minister of Agriculture, Fisheries and Food ex parte Fedesa (1990) Case C-331/88

SA Buitoni v Fonds d'orientation et de régularisation des marchés agricoles Case C-122/78

Robert-Gerardus Coenen and others v Sociaal-Economische Raad (1975) Case C-39/75

Roland Rutili v Ministre de l'intérieur Case C-36/75

Ferriera Padana SpA v Commission of the European Communities (1982) Case 276/80

Fédération Charbonnière de Belgique $v$ High Authority of the European Coal and Steel Community Case $8 / 55$

Federal Republic of Germany v Council of the European Union Case C-280/93

Balkan-Import-Export GmbH v Hauptzollamt Berlin-Packhof (1973) Case C5/73

Polydor Limited and RSO Records Incorporated v Harlequin Record Shops Limited and Simons Records Limited, Judgment, Case 270/80, (1982)

Gaston School, Case 15/81, (1982) 